Editorial

\title{
Party politics, the poor and the city: Reflections from the South African case
}

\section{Why reflect on political parties at the local level?}

Local democracy and 'spaces' of citizenship and participation are at the core of much contemporary research focusing on cities (Barnett and Low, 2004). This is the case both for researchers interested in issues of urban governance and social and spatial justice, around for instance the notion of 'right to the city', and also for those focusing on urban social dynamics and local identities. This is because local citizenship can be an important dimension of such identities and group formation, and local identities can profoundly impact the lived experiences of citizenship. Local democracy indeed, while not necessarily equivalent to deeper democracy or greater justice at the more general level (Purcell, 2006), at least opens avenues for the engagement of urban residents in debates about their immediate environment, including on issues dealing with the distribution or design of urban goods (housing, services, access to space). Notably absent from the literature focusing on local democracies on cities, and maybe more especially in African contexts, is the importance of party politics in the construction of local debates and urban citizenship. This is the gap that this themed issue begins to address.

Many authors have stressed the paramount importance for urban governance, and maybe even more in cities of the South, of party affiliations, patronage linkages and the political manipulation of ethnicity at a neighbourhood level (Cornwall and Coelho, 2007; Pieterse and Van Donk, 2008; Williams, 2004), and in low-income urban residents' livelihood strategies (Rakodi, 2009; Simone, 2004; Tostensen et al., 2001). However, studies on the place of party politics in local urban societies and their governance remain scarce or superficial, at least in Africa. ${ }^{1}$ This omission is all the more startling given the fact that clientelism has been a major theme in African studies (whether expressed as a form of neopatrimonialism: Eisenstadt, 1973, or prebendalism: Joseph, 1987). However, to date the literature on clientelism has focused on politics at the national level, characterising governance as a mix of Weberian rational-bureaucratic and patrimonial rule which can either co-exist or become interwoven such that personal patron-client relationships and practices come to dominate the way power works despite the formal system of rules.

\footnotetext{
1 The place of clientelism and local politics in Latin American cities seems to have been more widely explored, in more urbanised societies: Gay, 1998. Work by Partha Chatterjee on Indian politics (2004) enriches the debate on how to conceptualise the place of clientelism in urban societies of the South, where he argues that poor people are not citizens so much as populations which are managed (echoing Mamdani's (1996) accounts of elite constructions of political subjectivities), who engage in 'political' rather than 'civil society', and pursue public goods through clientelistic rather than democratic means. See Bénit-Gbaffou (2012) for a further elaboration on this theoretical framework.
}

Low (2007) explains the marginality of urban party politics in academic literature through the more common, and more prestigious, focus of political studies on broader scales of analysis: international or national, sometimes regional, but rarely at more local, city or neighbourhood levels. He adds that politics are generally morally discredited at the local level (being considered corrupt, the realm of personal interest and of quest for power or financial gain), and therefore seldom constitute an object for interest or research. However, the importance of local politics in the everyday lives of low-income residents, especially in cities of the South, as well as their constant intertwining with the practices of local democracy, the dynamics of civil society organisations, and residents' everyday lives and survival strategies, lead us to question their complex role in local societies and urban governance.

This themed issue, jointly proposed by a geographer (Claire Benit-Gbaffou) and a political scientist (Laurence Piper) sharing an interest in cities and politics, and determined to continue their engagement in a multi-disciplinary dialogue, ${ }^{2}$ proposes to start addressing this gap in a South African urban context, along the following sets of questions:

- What are the strategies used by political parties at the local level in order to gain influence and voter support? How important are the territorial dimensions of these strategies, or what are the spatial impacts of their strategies (in terms of representation of diversity on the one hand, and on segregation patterns on the other)? Do these strategies lead to an understanding of, and to proposed responses to, locally-expressed needs? What types of relationships do locally-grounded parties develop with civil society organizations and residents? Are they relationships of control and infiltration, co-optation, bargaining, forms of clientelism or perhaps even forms of local accountability? What identities and subjectivities are invoked, challenged or reinforced in this politics?

- How do residents and civil society organizations (civics, social movements, NGOs) relate to political parties? Are they able to challenge a mere 'voting cattle' or 'vote bank' status to try and bargain with political parties to access certain public goods, or influence certain local urban policies? Does political competition increase their chance of bargaining? Is there dependency

\footnotetext{
$\overline{2}$ This dialogue has developed within a research programme (2008-2011) entitled "The Voices of the Poor in Urban Governance: Participation, Mobilization and Politics in South African Cities". Coordinated by Claire Benit-Gbaffou and Alan Mabin, the programme is funded by the French Ministry of Foreign Affairs and supported by the French Institute of South Africa. It involves more than 25 French and South African researchers (confirmed and junior). One of the programme's research focuses is to analyse the place of political parties in conveying or sedating the voices of the poor in urban governance.
} 
and social pressure limiting their ability to bargain or protest against locally dominant political parties? Are there even forms of co-operation between local communities and political parties to address social problems?

- What potentialities exist for transforming local politics in a more democratic direction? How much is local politics defined by a middle-class 'civil society' and a poor 'political society' (Chatterjee, 2004)? To what extent does clientelism define local power, and how does it relate to political subjectivities and identity politics? Which local actors move politics in more democratic directions? More specifically does greater local party competition enhance or retard democratic local politics?

\section{Why South African cities?}

The issue is centred on the South African cities experience, which is understood as both particular in some ways, but also of broader interest for a general reflection on the role of the party in urban governance, in civil society dynamics, and in urban residents' livelihoods and access to resources.

South African cities' politics are specific as they are undergoing a dynamic democratization process after decades of apartheid, where the African National Congress (ANC) as the liberation party still plays a predominant, although increasingly contested role in local politics. We argue that they also are of broader relevance for a general understanding of party politics and the city, as the transformation of a mass resistance movement into the ruling party is at a crucial stage whereby political and social dynamics are more publicly visible than usual. Current attempts of the dominant party to take over entire neighbourhoods by fighting (sometimes physically) locally-grounded civil society organisations, and the debates that this trend give rise to, are a sign that many ordinary features of African cities and politics are crystallising at this very moment of South African political and urban history.

Our ambition is first to open urban and political geography to a robust dialogue with political studies, through the reflection on common objects grounded in urban local contexts and in a spatial understanding of citizenship, participation and governance. Secondly, we aim at using our focus on South African cities in this specific time of their political and urban trajectories to open a relatively new field of research: introducing party political studies into urban studies - as we argue party politics play a major role, especially in African cities, in understanding urban governance, and the peculiarities of local rule, local identities and mobilisations, as well as residents' everyday livelihood strategies of accessing and securing resources. Indeed, a key question that emerges is what kinds of local power exist alongside the formal and official and the implications for effective and democratic forms of governance into the future.

The collection of papers addresses the topic from different and complementary viewpoints, also contrasting several local contexts, such as Johannesburg (the economic capital with global ambitions, that is still an ANC uncontested stronghold), Cape Town (the main opposition party stronghold and second largest city in the country) and Msunduzi (a secondary city near Durban where some political competition between the ANC and the Zulu-based Inkatha Freedom Party gives a different political setting to local dynamics).

\section{Organisation of the themed issue}

Bénit-Gbaffou (2012) and Sinwell (2012) focus their study on political parties in various local political and urban contexts, in Johannesburg. Both papers firstly attempt to unravel party branches' relationships with other existing structures of civil society. These include the role of parties as brokering agents to access the state; as engaging to build a political clientele (with both positive and negative aspects); as offering a form of accountability to low income residents; and as also implementing forms of social control. A second focus of both papers is the analysis of local party branches' relationships with their party hierarchy (at supra local: metropolitan, regional or national levels), and question the extent of their ability to bring local issues to the attention of broader scales of government, in a form of bottom-up approach of urban governance that classical participatory structures have failed to follow. While Bénit-Gbaffou focuses on the ANC as the party in power (and therefore more able to distribute access to state resources), Sinwell centers his study on the Communist Party (in alliance with the ANC) and question the extent to which this political position can be used as a way of lobbying or influencing government to behave in more accountable ways.

Fourchard (2012) and Matlala and Bénit-Gbaffou (2012) deal with similar issues but from a different perspective, as their object of study focuses on political activists' identities, memories and practices, in Cape Town and Johannesburg townships respectively. They both emphasise the ambiguous and often deeply contradictory relationships entertained by former ANC activists with the ANC as it stands today - torn between a deeply grounded loyalty to the liberation party; an instrumental use of their political culture and memories of resistance; and their disappointment or even opposition to the current ANC policies that they try and match with the way they have constructed their political identity over time. What is interesting is that it is often neighbourhood issues, unresolved by the ANC (such as access to water or the question of housing eviction) that trigger oppositional forms of political identities. This ethnographic insight helps in understanding the depth of the party culture in contemporary low-income neighbourhoods in South African cities, and sheds a light on the ability of political parties to infiltrate and influence local civil society in South African cities.

Finally, Piper and Africa (2012) adopt a broader approach, centred on citizenship and its relationship with competitive electoral politics, in a city located in Kwazulu Natal, a province which has experienced a high degree of political violence as the ANC was competing regionally and locally with the Inkhata Freedom Party (IFP). Critical on liberal assumptions about the benefits of political competition in such a context, Piper and Africa rejoin Matlala and Bénit-Gbaffou in showing that engaging in protests against ANC policies does not mean shifting away one's political loyalty to the party. Indeed, they show through a quantitative survey that most of the people engaging in protests are the same as those engaging in participatory democracy - far from being two politically opposed groups. They further argue that mainstream political science analysis in South Africa which emphasises the primacy of race to understanding South African politics is of limited use in describing the actual practice of citizenship once the concept is broadened beyong the act of voting. In this regard at least, South Africa may have more in common with other African cities than is commonly assumed.

\section{Opening debates}

This collection of papers does not pretend to provide definite or firm answers to the questions raised in this introduction, but it engages stimulating debates around them. A first debate constructed by the collection is about the conceptual dichotomy between invented and invited spaces of participation. A second debate is about the theme of political loyalties, cultures and identities. South African is still in a post-liberation phase where the liberation party is dominant and embodying struggle identities. The issue of political competition and accountability in urban governance is raised in this context. 
All the papers engage, to some extent, with the conceptual dichotomy proposed by Cornwall (2004) and Miraftab (2006), between 'invited' and 'invented' spaces of participation - depending on who, from civil society groups or from the state (or any kind of power) initiates participatory interactions. In 'invited' spaces of participation, public authorities (or private developers) invite residents to raise their views or share their opinion on policies or projects, therefore remaining more or less in control of the agenda and the terms of the engagement. This is generally contrasted to more challenging, more oppositional 'invented' spaces of participation, initiated by social movements or groups of residents demanding responses, accountability, or change from the state. This conceptual opposition between a more cooperative, less oppositional form of engagement between residents and the state, and a more confrontational, more autonomous one, is doubled in a South African context by a practical opposition: between inefficient, sterile if not sedative invited spaces of participation as opposed to efficient, dynamic and creative invented spaces (Transformation, 2008).

Several authors engage in this debate. Sinwell shows how the formalisation of an invented space of participation (for informal residents blocking the access to the bridge to be built) into a negotiated settlement with local authorities and their invited spaces of participation (the partner residents forum) leads to their disempowerment and sedation. Central here was the brokerage of the Communist Party who initially considered representing independent candidates in an upcoming election (therefore supporting confrontation to the state) but who finally decided to respect the alliance with the ANC, thereby no longer needing to build its own local constituency and thus represent this interest group. Here, the issue of electoral politics decided at national level directly impacts on social movements' local strategies and ability (or not) to influence local urban governance - in a dense, low-income, and heavily politicised urban setting.

Piper and Africa, through a different approach (a quantitative survey rather than a qualitative case study) and in a different context, demonstrate that participants in protests or other invented spaces of participation are also those attending the invited meetings opening the question of whether they form a 'political stratum' (Dahl, 1961). This notion concurs with the conclusions drawn by Bénit-Gbaffou on the limited 'fluidity' of the core group of politicised or politically involved residents - as belonging there requires an 'investment' in terms of time, display of loyalty to the movement or party, construction of networks that are incrementally constructed. Sinwell and Matlala and Bénit-Gbaffou rather insist on the importance of political education at the local level - Sinwell deploring its inadequacy where the informal settlement residents lose political momentum because of limited strategising - while Matlala and Bénit-Gbaffou show how the alliance with a wide range of social movements opens up new political skills and opportunities for local activists.

While invited and invented spaces do not arguably involve radically different participants, Piper and Africa insist that invited spaces of participation are 'ineffective' and even 'sterile', and that inventing one's own terms of engagement with the state is a possible response to frustrations encountered in these platforms. This is confirmed by Matlala and Bénit-Gbaffou and by Bénit-Gbaffou, when they show how the blockage of invited participation, the deafness of the state to low-income residents' claims, and the impossibility of competitive electoral politics, lead to more radical and possibly more violent forms of participation. While Matlala and Bénit-Gbaffou's activists justify their illegal actions as a continuation of their struggle activism, Bénit-Gbaffou stresses that the ANC's intolerance for dissent and its ability to socially control a number of (invited) public platforms leads to opposition being expressed outside invited spaces - in invented spaces that governments and parties have limited grasp on, and therefore tend to repress violently, taking a partial responsibility for the violent forms taken by recent protests.

Further debates however occur about the 'sterility' of invited spaces of participation - an even more severe statement (Piper and Africa, 2012) than their inefficiency. Bénit-Gbaffou and Fourchard concur generally on the relative inefficiency of these platforms as ways of shaping or influencing urban governance, policies or projects, but they both attempt to unravel the possible other social functions that invited spaces of participation perform, based on the functional argument of their existence, persistence, relative attractiveness in terms of audience. Bénit-Gbaffou argues that government invited spaces are key to display political loyalty, maintain and expand one's political network in a client-patron type of relationship with local councillors as well as local party representatives. Hence they are a crucial way of accessing the state and possibly its resources, where the party channels replace dysfunctional local government participatory structures. In addition there may be other forms of invited spaces (invited by the party rather than by local government as the two are intertwined anyway), that lead to the reproduction of existing power structures and involve a degree of local social control by putting a cap on challenges to policies and powers, but also constitute a resource in terms of political networks and possible access to public goods. Fourchard, looking at community policing invited spaces of participation, also understands them (in the context of a much more party politically contested city: Cape Town) as spaces for the distribution of public resources in exchange for the display of political loyalty. Notably, the use of terms and repertoires of mobilisation come from the anti-apartheid struggle (ANC aligned or not), and the use of these is central to displaying loyalty or even campaigning for a specific party. Invited spaces of participation, currently multiplying in an era of participatory and decentralised governance, are here clearly seen by competing parties as ways of consolidating or developing local strongholds, through the visible distribution of resources for instance.

The papers of this collection enter in a second type of debate, on the question of political identities and their embeddedness in history, the political cultures and repertoires that are mobilised and re-invented in order to suit contemporary political needs and opportunities; contradicting belongings or loyalties and the way activists manage them. Contradictions in political loyalties are considered from a variety of perspectives. Piper and Africa, adopting a quantitative approach, contrast the criticisms leveraged against the ANC (as illustrated by mass urban protests) and the same voters' loyalty to the ANC nevertheless (expressed through vote or level and 'trust'). While they partially confirm previous analyses (Friedman, 2005; Lodge, 2005) of the ANC as a party representing Black identity as well as the legacy of the struggle which supporters cannot betray even if they become critical of the party policies, they interestingly nuance this racial politics by complexifying the notion of citizenship - generally too much centred around the notion of electoral behaviour and not enough on other dimensions of citizenship, activism, protest and political identity. Matlala and Bénit-Gbaffou, through a qualitative survey of local activists, focus their paper on the management of these contradictions at a personal level, when analysing the discourses and tactics of antiANC social movement activists still holding to their ANC membership card, in a form of schizophrenic understanding of the ANC (the ANC versus 'the real' ANC; spirit of the ANC - struggling against oppression- as opposed to its current embodiment; local ANC as opposed to national ANC). In Piper and Africa's terms, they would tend to show that the different dimensions of citizenship are not always easy to hold together, at a personal level.

The local civic members interviewed by Fourchard seem to dwell far less on the memories of the struggle, subsumed as they 
are under the daily battles of survival. Indeed, the competing political slogans chosen for their action are more meaningful at metropolitan and provincial level where an acute political competition is underway, than at the local level where it is more a matter of accessing resources through a variety of channels. Activists interviewed by Sinwell rely on localised memories of urban mobilisation, and the ongoing competition between 'insiders' and 'outsiders', as relevant in a context of urban renewal as it was under apartheid. Notably, this mobilisation does not look to contest the rationale for urban renewal itself and the eviction processes it might entail. The issue is not the policy but the place of the group in the implementation of policy. In this way Sinwell demonstates the ambiguities of the Communist Party when confronted with issues of urban renewal, on the one hand caught between its general policy of supporting the oppressed and working 'on the ground', its local embededness in the local informal settlement where the protest starts and its sympathy to the residents claims; and, on the other hand, its alliance with the ANC at a time (elections) when full alignment with the party becomes crucial. Clearly in this case shifting electoral politics (from possible autonomy to confirmed alliance) dictated eventually the way the Communist Party shaped and influenced local civics mobilisations from contest to cooperation.

Obviously this continued loyalty for the ANC, in spite of rising criticisms and social tensions (frequently expressing themselves violently, as was the case in the 2008 wave of xenophobic attacks) raises the question of the links between political competition and democratic accountability. The urban local scale (ward, metropolitan council, or even provincial government) is the most likely to see the rise of competitive politics and the question of accountability takes a specific meaning at this local level, especially in a framework of decentralisation and participation on issues of urban policy, local projects, access to urban services, facilities and spaces. Local and regional contexts determine to a great extent the value of political competition to enhance local democratic accountability, and the authors of this collection have different views on the impact of political competition on both urban governability and democratic accountability.

Piper and Africa, writing from a Kwazulu Natal context where political violence between the ANC and the Inkatha Freedom Party has been rife, argue that liberal assumptions equating political competition with increased local accountability and better governance are currently wrong for South Africa. Fourchard, writing from an opposition-led Cape Town municipality, seemingly concurs with this view, showing that political competition between the opposition-led municipality and ANC-led provincial (no longer so today) and national government, lead them to multiply competing community policing institutions as means of consolidating political strongholds, at the expense of policing and urban management efficiency. On the other hand, Bénit-Gbaffou and Sinwell, both from a Johannesburg perspective, where the ANC is at no risk of losing power at a metropolitan nor provincial level, but which is also at the forefront of socio-economic, urban and political change, stress the importance of a party political alternative to put pressure on local government, in a more peaceful and less demanding way than through mass protests. The final consolidation of the alliance between the Communist Party and the ANC led the former to abandon the pressure it was putting for better urban solutions for informal Alexandra dwellers. The possibility of bargaining political support for access to collective resources seems to be slowly emerging as a tactic for the more politically astute local leaders although both party loyalty and party dominance prevents them from doing it confidently.

However, beyond the question of local urban and political contexts which determine whether the rules of the game are accepted or not by political players, and indicates whether political compe- tition leads to increased accountability or increased division and violence, the collection of papers raises an interesting point how to understand the articulation between the 'petty politics' of competitive elections and the 'high politics' of urban governance, right to the city, construction of citizenry, etc.? Piper and Africa argue that political competition absorbs the energies and resources of politicians and officials in partisan power-struggles, inside and outside of government, undermining responsive delivery and responsible decision-making, and asks how much a government gets done in an election year compared to a non-election year.

A similar discussion had developed within the 2008 issue of Transformation (on South African urban local government) where Deacon and Piper (2008) argued that ward committees were inefficient participatory institutions because of their heavy politicisation - while Bénit-Gbaffou (2008) tended to think that politicisation was unavoidable as intrinsic to democracy, and possibly fostering democratic debate. The 2011 campaign for local elections in South Africa, where various ANC candidates were asked to present their vision to the public at the ward level, might not lead to delivery but it certainly offers a variety of possible futures (of leaders, discourses, and visions for the area and the community). This is not to deny there are everyday experiences of the damages incurred and energies consumed in petty politics. Indeed, all those who have researched urban politics, or been involved in them, have been confronted by this conundrum, and have witnessed politicking destroy the impetus for constructing social change (Bénit-Gbaffou, 2010).

Are there not however other ways of understanding petty politics as mere hindrances to more 'noble' forms of politics, urban governability, accountability, democratic debate? This path of reflection seems to be developing, as discussions are rife amongst academics writing on social movements, on whether it is important, useful, and politically wise, to open the black box of their petty politics at the risk of undermining the causes they fight for (Appadurai, 2002); on the other hand, the romanticisation of social movements and the sympathetic blindness towards their internal conflicts and politics are more and more criticised (Kapoor, 2004). As Chatterjee (2004) warns, if we ignore what he calls 'the political society' (petty politics) and only focus on 'civil' society (civilised politics?) we might well give up understanding most of the world.

\section{References}

Appadurai, U., 2002. Deep democracy: urban governmentality and the horizon of politics. Public Culture 14 (1), 21-47.

Barnett, C., Low, M. (Eds.), 2004. Spaces of Democracy: Geographical Perspectives on Citizenship, Participation and Representation. Sage, London.

Bénit-Gbaffou, C., 2008. The place of participation in South African local democracy - introduction to the special issue: South African local government. Transformation: Critical Perspectives on Southern Africa 66-67, i-vii.

Bénit-Gbaffou, C., 2010. The researcher as a ball in a political game. Carnets de Géographes, No. 1. <http://www.carnetsdegeographes.org/carnets_terrain. php>.

Bénit-Gbaffou, C., 2012. Party politics, civil society and local democracy - reflections from Johannesburg. Geoforum 43 (2), 178-189.

Chatterjee, P., 2004. The Politics of the Governed: Popular Politics in Most of the World. Columbia University Press, Columbia.

Cornwall, A., 2004. Spaces for transformation? Reflections on issues of power and difference in participation in development. In: Hickey, S., Mohan, G. (Eds.) Participation from Tyranny to Transformation: Exploring New Approaches to Participation in Development. Zed Books, London and New York, pp. 75-91.

Cornwall, A., Coelho, V.S. (Eds.), 2007. Spaces for Change? The Politics of Citizen Participation in New Democratic Arenas. Zed Books, London.

Dahl, R., 1961. Who Governs? Democracy and Power in an American City. Yale University Press, New Haven and London.

Deacon, R., Piper, L., 2008. Party politics, elite accountability and public participation: ward committee politics in the Msunduzi Municipality. Transformation: Critical Perspectives on Southern Africa 66-67, 61-82.

Eisenstadt, S.N., 1973. Traditional Patrimonialism and Modern Neopatrimonialism. Sage, Beverly Hills. 
Fourchard, L., 2012. Security and party politics in Cape Town. Geoforum 43 (2), 199 206.

Friedman, S., 2005. A voice for some: South Africa's ten years of democracy. In: Piombo, L., Nijzink, L. (Eds.), Electoral Politics in South Africa: Assessing the First Democratic Decade. Palgrave MacMillan, New York, pp. 3-22.

Gay, R., 1998. Rethinking clientelism: demands, discourses and practices in contemporary Brazil. European Review of Latin American and Caribbean Studies 65, 7-24.

Joseph, R.A., 1987. Democracy and Prebendal Politics in Nigeria: The Rise and Fall of the Second Republic. Cambridge University Press, Cambridge.

Kapoor, L., 2004. Hyper-Self-Reflexive Development: Spivak on representing the Third World Other. Third World Quarterly 25 (4), 627-647.

Lodge, T., 2005. The African National Congress: there is no party like it - ayikho efana nayo. In: Piombo, J., Nijzink, L. (Eds.), Electoral Politics in South Africa: Assessing the First Democratic Decade. Palgrave MacMillan, New York, pp. 109-128.

Low, M., 2007. Political parties and the city: some thoughts on the low profile of partisan organisations and mobilisation in urban political theory. Environment and Planning 39 (11), 2652-2667.

Mamdani, M., 1996. Citizen and Subject: Contemporary Africa and the Legacy of Late Colonialism. Princeton University Press, New Haven, Mass.

Matlala, B., Bénit-Gbaffou, C., 2012. Against ourselves - local activists and the management of contradictory political loyalties: the case of Phiri, Johannesburg. Geoforum 43 (2), 207-218.

Miraftab, F., 2006. Feminist praxis, citizenship and informal politics: reflections on South Africa's anti-eviction campaign'. International Feminist Journal of Politics 8 (2), 194-218.

Pieterse, E., Van Donk, M., 2008. Developmental local government: squaring the circle between policy intent and impact. In: Van Donk, M., Swilling, M., Pieterse, E., Parnell, S. (Eds.), Consolidating Developmental Local Government: Lessons from the South African Experience. UCT Press, Cape Town, pp. 51-76.

Piper, L., Africa, C., 2012. Unpacking Race, Party and Class from Below: Surveying Citizenship in the Msunduzi Municipality. Geoforum 43 (2), 219-229.
Purcell, M., 2006. Urban democracy and the local trap. Urban Studies 43 (11), 1921 1941.

Rakodi, C., 2009. Planning, Participation and Politics. Global Report on Human Settlements 2009: Revisiting Urban Planning. UN-Habitat, Nairobi, pp. 93-110 (chapter 5).

Simone, A., 2004. For the City Yet To Come: Changing African Life in Four Cities. Duke University Press, Durham.

Sinwell, L., 2012. Transformative left-wing parties' and grassroots organizations: unpacking the politics of "Top-Down" and "Bottom-Up" development. Geoforum 43 (2), 190-198.

Tostensen, A., Tvedten, I., Vaa, M. (Eds.), 2001. Associational Life in African Cities: Popular Responses to the Urban Crisis. Elanders Gotab, Stokholm.

Claire Bénit-Gbaffou (Eds.), 2008. Transformation: Critical Perspectives on Southern Africa (special issue on 'South African local government', vols. 66-67).

Williams, G., 2004. Evaluating Participatory Development: tyranny, power and (re)politicisation. Third World Quarterly 25 (3), 557-579.

Claire Bénit-Gbaffou

School of Architecture and Planning, Wits University, Private Bag 3, WITS 2050, Johannesburg, South Africa Tel.: +27 1171777 18; fax: +27 865535232 . E-mail address: claire.benit@wits.ac.za

Laurence Piper

Dpt. of Political Studies, University of the Western Cape, Private Bag X17, Bellville 7535, South Africa Tel.: +27 021959 3234; fax: +27 0219593621. E-mail addresses: laurencepiper@gmail.com, lpiper@uwc.ac.za

Available online 20 January 2012 